\title{
Effect of using different fertilizers sources on forage sorghum yield, digestibility and energy parameters by In vitro Gas Test production
}

\author{
El-Sherbini M. Heseen ${ }^{1}$, Mervat S. Hassan ${ }^{2}$, Azza M. M. Badr' ${ }^{2}$ Fatma Sh. Ismail, ${ }^{3}$ and Fatma Abd- \\ Elsalam A. ${ }^{2}$ \\ ${ }^{1}$ Soil Science Department, Faculty of, Agriculture, Cairo University, Egypt. \\ ${ }^{2}$ Regional center for food and feed, Agriculture Research Center, Giza, Egypt. \\ ${ }^{3}$ Forage Crops Research Department, Field Crops Research Institute, Agric. Res. Center, Giza, Egypt.
}

\begin{abstract}
The effect of using different rates of organic and mineral fertilization on forage sorghum was studied. An experiment was conducted at the Agricultural Research and Experimental Station, Cairo University in 2013 and 2014 summer seasons. The experiment was performed in a randomized complete design with three replicates. The experiment included five treatments; the $\mathrm{T}_{1}$ (control) $=100 \%$ mineralization, $\mathrm{T}_{2}\left(\mathrm{C}_{6} \mathrm{M}_{0}\right)=100 \%$ compost, $\mathrm{T}_{3}$ $\left(\mathrm{C}_{4.5} \mathrm{M}_{25 \%}\right)=25 \%$ minerals $+75 \%$ compost, $\mathrm{T} 4\left(\mathrm{C}_{3} \mathrm{M}_{50 \%}\right)=50 \%$ minerals $+50 \%$ compost and $\mathrm{T}_{5}\left(\mathrm{C}_{15} \mathrm{M}_{75 \%}\right)=$ $75 \%$ minerals $+25 \%$ compost. The results showed significant increases in plant height, stem thickness, fresh weight and dry weight for the $\mathrm{T}_{3}$ compared with the other treatments, while means value were $152.4 \mathrm{~cm}, 1.047$ $\mathrm{cm}, 22.96$ ton. /fed and 6 ton/fed, respectively. Moreover, $\mathrm{T}_{3}\left(\mathrm{C}_{4.5} \mathrm{M}_{25 \%}\right)$ led to increasing the content of $\mathrm{CP}$ and NFE and did not affect the EE and ash. While this treatment led to increasing the content of NDF\%, ADF\% and decreasing the content of hemi cellulose and higher content of cellulose compared to the other treatments. The results of gas parameters correct (GP $\mathrm{ml} / 200 \mathrm{mg} \mathrm{DM}$ ), gas production structure fraction (GPSF \%) and gas production non-structure fraction (GPNSF \%) recorded the best values with the $\mathrm{T}_{2}\left(\mathrm{C}_{6} \mathrm{M}_{0}\right)$. The highest values of each of (GP ml / $200 \mathrm{mg}$. DM), (GPSF \%) and (GPNSF \%) was recorded in the $1^{\text {st }}$ and $2^{\text {nd }}$ cut, while the $\mathrm{T}_{4}$ $\left(\mathrm{C}_{3} \mathrm{M}_{50 \%}\right)$ gave the highest value in the $3^{\text {rd }}$ cut. The $\mathrm{T}_{2}$ recorded the highest values of $\mathrm{ME}(\mathrm{MJ} / \mathrm{Kg}$. DM) in the $1^{\text {st }}$ cut and the net energy lactation (NEL $\mathrm{MJ} / \mathrm{kg}$.DM) in the $2^{\text {nd }}$ cut. The short-chain fatty acids (SCFA, $\mathrm{s} \mathrm{m} \mathrm{mol} / \mathrm{ml}$. gas) showed the highest values in the $1^{\text {st }}$ and $2^{\text {nd }}$ cut, while for the $\mathrm{T}_{4}\left(\mathrm{C}_{3} \mathrm{M}_{50 \%}\right)$ showed the highest values in the $3^{\text {rd }}$ cut. The $\mathrm{T}_{2}$ recorded a significant increase in dry matter and organic matter digestibility in the $1^{\text {st }}$ cut followed by the $\mathrm{T}_{4}$ which recorded the highest value in the $1^{\text {st }}$ cut. The economic study proved that the $\mathrm{T}_{3}\left(\mathrm{C}_{4.5} \mathrm{M}_{25 \%}\right)$ has the highest profit (2.29 L.E.), the $\mathrm{T}_{4}=(2.46 \mathrm{~L}$.E. $)$ and the lowest return of the $\mathrm{T}_{2}=100 \%$ organic gave a profit of $\left(1.90 \mathrm{~L}\right.$. E.). The $\mathrm{T}_{2}$ gave the highest digestive value for the $1^{\text {st }}$ and $2^{\text {nd }}$ cut, followed by the $T_{4}$ which gave the highest digestive value in the $3^{\text {rd }}$ cut. Finally, we can conclude that the $T_{2}$ is the best treatment in terms of feeding animal and the size of the crop in the $2^{\text {nd }}$ cut is like the size of the crop in the $3^{\text {rd }}$ cut of the $T_{4}$, which gave the best economic feasibility using the $2^{\text {nd }}$ cut of the $T_{2}$ to provide the time of cultivation for another crop. In addition, necessary work of the digestion and feeding trails on the animal on these $2^{\text {nd }}$ cut of $T_{2}$ which gave positive results in order to link the amount of yield in the $1^{\text {st }}$ and $2^{\text {nd }}$ cut and digestion factors and measure the amount of meat produced to determine the economic efficiency in obtaining a good crop in arms of quantity and quality and reduce the crop duration to provide land for cultivation another crop as well as reducing the mineral contamination of the fertilizer-producing soil.
\end{abstract}

Key words: Forage Sorghum, organic and mineral fertilization, plant growth, chemical composition, In- vitro gas test and Economic evaluation.

\section{Introduction}

Forage Sorghum is one of the most widely adapted forage crops and grown extensively during summer season and has a significant role in livestock production (Amandeep, 2012). Nitrogen is the essential element required for plant growth in relatively large amounts. $\mathrm{N}$ deficiency can result in reduced dry matter, crude protein and grain yield (Ashiono et al., 2005). The nitrogen is important component of proteins, enzymes, vitamins, chlorophyll and essential photosynthetic molecule (Basak 2006).

Compost had positive effect on plant growth and yield due to its high organic matter content which improved soil physical and biological properties
(Gupta and Pradhan 1995). Feeding of green forage to livestock is essential for the maintenance of normal health and reproduction (Roy and Khandaker 2010).

Recently in vitro gas production technique with chemical composition have been widely used to evaluate the potential nutritive value of previously uninvestigated forages since in vitro gas production technique is quick, cheap and less time consuming (Kamalak and Canbolat 2010, Getachew et.al., 2004; Chumpawadee et.al., 2005 and Maheri-Sis et.al., 2007, 2008). In vitro rumen degradability and gas production (GP) techniques have been used for estimating quality of feed sorghum for ruminants. This method also predicts gas production correct, gas production structure fraction, gas production non- 
structure fraction, dry matter digestibility, organic matter digestibility and amount for short chain fatty acids of ruminants feed and energy parameters energy. Babayemi, (2007) and Maheri-Sis et.al., (2008) who reported highly significant $(\mathrm{p}<0.01)$ variations on DM content among the three fodders in the first and third cuts and the highest values $(58.35,59.97$ and $61.92 \%)$ of IVDMD were found in German grass compared to those of para and dhal grasses in all stages of maturity. The gas production of different classes of feed incubated in vitro in buffered rumen fluid was closely related to the production of SCFA, $\mathrm{s}$ which was based on carbohydrates fermentation (Sallam et.al., 2007, Kanak et.al., 2012 and Blummel and Oraskov 1993).

The objectives of the present study were to determine the effect of inorganic nitrogen (in form of ammonium nitrate $33.5 \%$ ) and organic nitrogen (in form compost of residual of plants mixed with animal manure) with different combination between them on yield and quality of forage Sorghum. The final product was determining the chemical composition, In-Vitro rumen degradability, parameters gas production and volatile fatty acid production to elucidate the relationships between chemical composition and energy parameters of InVitro rumen degradability.

\section{Materials and Methods}

The field experiment was carried out at the Experimental West Farm of Research Station of Faculty of Agriculture, Cairo University, Egypt during summer seasons 2013 and 2014, to study the effect of inorganic nitrogen (in form of ammonium nitrate $33.5 \%$ ) and organic nitrogen in form of compost with different combinations between them on yield and quality of forage sorghum.

Plot size was $12 \mathrm{~m}^{2}$ (4 X $3 \mathrm{~m}$ ) compressing five ridges $60 \mathrm{~cm}$ apart and $25 \mathrm{~cm}$ between hills. Phosphorus fertilizer $\left(15.5 \% \mathrm{P}_{2} \mathrm{O}_{5}\right)$ in the form of super phosphate was applied at the rate of $100 \mathrm{~kg} / \mathrm{fed}$ during soil preparation. Nitrogen of ammonium nitrate $(33.5 \% \mathrm{~N})(90 \mathrm{~kg} \mathrm{~N} / \mathrm{fed})$ was added in three equal doses i.e. $30 \mathrm{~kg}$ just after the $1^{\text {st }}$ irrigation plus $30 \mathrm{~kg}$ after $1^{\text {st }}$ cut and $30 \mathrm{~kg}$ after $2^{\text {nd }}$ cut. Three cuts were taken from each experiment; the $1^{\text {st }}$ cut was taken after 55 days from seeding, date the $2^{\text {nd }}$ cut at 35 days from the $1^{\text {st }}$ cut, the $3^{\text {rd }}$ cut after 35 day from the $2^{\text {nd }}$ cut. Potassium sulphate $\left(48 \% \mathrm{~K}_{2} \mathrm{O}\right)$ was applied at rate of $75 \mathrm{~kg} / \mathrm{fed}$ on two equal doses after 20 and 40 days from planting. The experiment was laid out in Complete Randomized Block Design (RCBD), using three replications.

The soil of the experimental field was clay loam, neutral (pH 7.97); EC 0.98dSm-1, Organic matter (0.65\%), available N 38.96, P 4.28 and K $189 \mathrm{mg} / \mathrm{kg}$ soil. The chemical properties of the cultivated soil were determined before sowing according methods described by Cottenie, et. al. (1982) and Page et al (1982). Compost was prepared according to (Nasef et. al., 2009). The final product was chemically analyzed by Brunner and Wasmer (1978). The chemical analysis of compost is recorded in five treatments was applied as followed: T1= C0 M 100\% (control); T2= Compost 100\% (C6 M0); T3 = C4.5 $\mathrm{M} 25 \%$; $44=\mathrm{C} 3 \mathrm{M} 50 \%$ and $\mathrm{T} 5=\mathrm{C} 1.5 \mathrm{M} 75 \%$.

\section{1- Preparing the samples:}

The same time freshly collected leaves samples from each plot were cut into small pieces and dried for determining chemical analysis and feeding value. The chemical composition of compost is recorded in Table (1).

2.2-Chemical analysis: Samples were sieved after dried and milled through a $1 \mathrm{~mm}$ sieve for chemical analysis and in vitro gas production procedure. Dry matter (DM) was determined by drying the samples at $105^{\circ} \mathrm{C}$ overnight and ash by igniting the samples in muffle furnace at $525^{\circ} \mathrm{C}$ for $8 \mathrm{~h}$. Nitrogen (N) content was measured by the kjeldahl method. Crude protein $(\mathrm{CP})$ was calculated as $\mathrm{N} * 6.25$, crude fiber (CF) and ether extract (EE) was determined according to AOAC (2000). Neutral Detergent Fiber (NDF), Acid detergent fiber (ADF) and acid detergent lignin (ADL) were determined according to the producers outlined by Van- Soest et. al., (1991).

\section{3-Parameters In-vitro rumen gas test production:}

In-Vitro rumen gas production parameters were carried out in the Laboratory of Total nutrient digestibility, Regional Center for Food and Feed, Agriculture Research Center, Giza, Egypt. Rumen fluid was obtained from three fistulae Rahmani rams fed twice daily at the maintenance level with a diet containing alfalfa (60\%) and concentrate (40\%). The samples were incubated in vitro with rumen fluid in calibrated glass syringes following the procedures of Menke et.al., (1979). Two hundred Milligram dried samples were weighed in triplicate into calibrated glass syringes of $100 \mathrm{ml}$. The syringe were prewar med at $39^{\circ} \mathrm{C}$ before the injection of $30 \mathrm{ml}$ rumen fluid-buffer mixture into each syringe followed by incubation in a water bath at $39^{\circ} \mathrm{C}$. Readings of gas production were recorded. Total gas values were corrected for blank incubation. Digestible Dry Matter (DDM), Digestible Organic Matter (DOM), Short Chain Fatty Acids SCFA,s, Gas Production Soluble Fraction (GPSF) and Gas Production Non- Soluble Fraction (GPNSF) were calculated according to van Gelder et. al. (2005), Metabolizable Energy (ME), Net Energy Lactation (NEL), Digestible Organic Matter (DOM) and Digestible Dry Matter (DDM) values were calculated using equations below according to Menke and steingass. (1988).

SCFA $=0.0239 *$ gas -0.00425 . 
GPSF $(\mathrm{ml} / \mathrm{g} \mathrm{DM})=($ Gas3h.-5.5 $) * 0.99-3$. GPNSF $(\mathrm{ml} / \mathrm{g} \mathrm{DM})=(1.02 *($ Gas24h-5.5) $-($ Gas3h5.5) +2$)$.

DOM $=33.71+(0.7464 *$ gas $)$.

$\mathrm{ME}=2.2+0.1357 *$ gas $+0.057 * \mathrm{CP}+0.002859 * \mathrm{CP} 2$.

$\mathrm{NEL}=0.54+0.0959 *$ Gas + 0.0038 $* \mathrm{CP}+$ $0.0001733 * \mathbf{C P}$

2.4-Economic evaluation: In the present study, the economic evaluations are based on the official and actual market prices determined by Muhamed
Abd El - Halim Ministry of Agriculture and the Agricultural Credit and Development Bank in Giza.

\section{5-Statistical analysis:}

The statistical analysis was done using MSTATC program in a Completely Randomized Block Design (CRBD), and differences among the treatment means were determined by the Least Significant Difference (LSD) for comparing means at 5\% level according to Gomez, and Gomez, (1984).

Table 1. Chemical analysis of the compost

\begin{tabular}{ccccccccc}
\hline EC $(\mathbf{D S} / \mathbf{m})$ & $\begin{array}{c}\text { pH (paste } \\
\text { extract) }\end{array}$ & $\begin{array}{c}\text { Moisture } \\
(\boldsymbol{\%})\end{array}$ & $\begin{array}{c}\text { O.M. } \\
(\boldsymbol{\%})\end{array}$ & $\begin{array}{c}\text { O.C. } \\
(\boldsymbol{\%})\end{array}$ & $\begin{array}{c}\text { C/N } \\
(\boldsymbol{\%})\end{array}$ & \multicolumn{3}{c}{\begin{tabular}{c} 
Macronutrients \\
\cline { 5 - 8 }
\end{tabular}} \\
\hline 4.68 & 8.33 & 14.40 & 55.34 & 32.10 & 19.38 & 1.70 & 0.21 & $\mathbf{\text { K }}$ \\
\hline
\end{tabular}

O.M. = organic matter, O.C. $=$ organic carbon, $\mathrm{C} / \mathrm{N}=$ ratio of carbon in nitrogen

Table 2. Plant height and Stem diameter of forage sweet Sorghum as affected by organic and mineral fertilizers for grand mean for two seasons:

\begin{tabular}{|c|c|c|c|c|c|c|c|c|}
\hline \multirow[b]{2}{*}{ Treatments } & \multicolumn{3}{|c|}{ Plant height $\left(\mathrm{cm}^{2}\right)$} & \multirow[b]{2}{*}{ Means } & \multicolumn{3}{|c|}{ Stem diameter $\left(\mathrm{cm}^{2}\right)$} & \multirow[b]{2}{*}{ Means } \\
\hline & $1^{\text {st }} \mathrm{Cut}$ & $2^{\text {nd }} \mathrm{Cut}$ & $3^{\text {rd }}$ Cut & & $\begin{array}{l}1 \text { st. } \\
\text { Cut }\end{array}$ & $2^{\text {nd }}$ Cut & $3^{\text {rd }}$ Cut & \\
\hline$T_{1}(\mathrm{C} 0 \mathrm{M} 100 \%)$ & 154.5 & 157.5 & 118.6 & 143.5 & 0.897 & 1.033 & 0.89 & 0.94 \\
\hline$T_{2}=(C 6 M 0)$ & 166.7 & 170.7 & 132.5 & 156.6 & 0.883 & 0.983 & 0.857 & 0.907 \\
\hline $\mathrm{T}_{3}(\mathrm{C} 4.5 \mathrm{M} 25 \%)$ & 168.0 & 173.6 & 152.4 & 164.7 & 1.007 & 1.167 & 0.967 & 1.047 \\
\hline $\mathrm{T}_{4}=\mathrm{C} 3 \mathrm{M50} \%$ & 150.2 & 160.9 & 137.7 & 149.6 & 0.883 & 1.047 & 0.763 & 0.898 \\
\hline$T_{5}=(C 1.5 M 75 \%)$ & 154.3 & 166.2 & 141.7 & 154.1 & 0.903 & 1.033 & 0.867 & 0.934 \\
\hline $\begin{array}{l}\text { L.S.D. at } 0.05 \\
\text { levels }\end{array}$ & \multicolumn{3}{|c|}{$\begin{array}{l}\text { Treatments }(T)=1.901 \\
\text { Cuts }(C)=1.473 \\
\text { Interaction }(T \times C)=3.293\end{array}$} & & \multicolumn{3}{|c|}{$\begin{array}{l}\text { Treatments }(T)=0.048 \\
\text { Cuts }(C)=0.0374 \\
\text { Interaction }(T \times C)=0.1803\end{array}$} & \\
\hline
\end{tabular}

\section{Results and Discussion}

3.1- Compost and the mineral additions effects on yield properties of sorghum cultivars:

3.1.1- Plant height and stem diameter: We observed that the compost and mineral fertilizers were affected plant height and stem diameter, where it was ranged from 118.6 to $173.6 \mathrm{~cm}$. and 0.763 to $1.167 \mathrm{~cm}$. for both of plant height and stem diameter, respectively. The T3 gave the highest values of plant height and stem diameter where it recorded 173.6 and $1.167(\mathrm{~cm})$ compared with the other treatments. The statistical analysis it was observed that $T_{3}$ rates at $2^{\text {nd }}$ Cut gave highest value of plant height. The interaction between rates and cuts gave highly significant values for stem diameter. These results are in consistence with Ahmad et al., (2009), ElSabbagh, N. (2001), Farhad et al., (2009), Khaled et al., (2011). Muhmmad et al., (2014) in one $\mathrm{T}_{3}$ treatment at ${ }^{2 n d}$ Cut better than other treatments. These results also agree with that obtained by Mahmoud et al, (2013). On the other hand, Jaime and Viola (2011) found that stem diameter was not affected by the different basal rates applied in this trial with combinations of inorganic fertilizers and composts.

3.1.2- Fresh and dry weight. Data in Table (3) showed that fresh and dry weight values of forage sorghum plants were affected by different application rates of organic and inorganic fertilizers, where the addition rate of 4.5 ton compost $+25 \% \mathrm{NPK} / \mathrm{fed}$ mineral fertilizer $\left(\mathrm{T}_{3}\right.$ at $\left.2^{\text {nd }} \mathrm{Cut}\right)$ gave the highest values of both fresh and dry weight compared with the other treatments, it was ranged 17.68 to 30.77 and 4.07 to 7.52 ton/fed respectively. The interaction between application rates and cuts revealed that there was significant effect. These results almost agree with that obtained by Hanan Siam et. al., (2014) and Iqbal et.al., (2014), who reported that the use of compost at the rate of $20 \mathrm{~m}^{3} / \mathrm{fed}$ (O.M) in combination with the high rate of nitrogen fertilizer had significantly affected the dry matter content. Generally, the fresh and dry weight values were increased when $\mathrm{T}_{3}$ compared with the control where the per-cent was $9.14 \%$ and $9.88 \%$ respectively. Ghosh et. al., (2004), Khan et.al., (2008) and Aspasia et. al., (2010). 
Table 3. Grand mean of fresh and dry weights of forage Sorghum as affected by organic and mineral fertilizers during two seasons

\begin{tabular}{|c|c|c|c|c|c|c|c|c|}
\hline \multirow[b]{2}{*}{ Treatments } & \multicolumn{3}{|c|}{ Fresh weight (ton. /fed) } & \multirow[b]{2}{*}{ Means } & \multicolumn{3}{|c|}{ Dry weight (ton. /fed) } & \multirow[b]{2}{*}{ Means } \\
\hline & $\begin{array}{l}1 \text { st. } \\
\text { Cut }\end{array}$ & $2^{\text {nd }} \mathrm{Cut}$ & $3^{\text {rd }}$ Cut & & $\begin{array}{l}1 \text { st. } \\
\text { Cut }\end{array}$ & $2^{\text {nd }} \mathrm{Cut}$ & $3^{\text {rd }} \mathrm{Cut}$ & \\
\hline $\mathrm{T}_{1}(\mathrm{C0M100 \%})$ & 24.92 & 27.3 & 19.92 & 24.05 & 5.20 & 5.95 & 4.73 & 5.29 \\
\hline $\mathrm{T}_{2}=(\mathrm{C} 6 \mathrm{M0})$ & 25.69 & 28.63 & 17.68 & 24.00 & 5.38 & 6.85 & 4.09 & 5.44 \\
\hline $\mathrm{T}_{3}(\mathrm{C} 4.5 \mathrm{M} 25 \%)$ & 28.95 & 30.77 & 22.96 & 27.56 & 5.58 & 7.52 & 4.9 & 6.00 \\
\hline$T_{4}=$ C3M50\% & 28.84 & 28.91 & 19.71 & 25.82 & 5.19 & 5.91 & 4.45 & 5.18 \\
\hline $\mathbf{T}_{5=}(\mathrm{C} 1.5 \mathrm{M} 75 \%)$ & 26.39 & 28.25 & 21.98 & 25.54 & 5.49 & 6.69 & 4.07 & 5.42 \\
\hline L.S.D. at 0.05 levels & $\begin{array}{l}\text { Treatments } \\
\text { Cuts } \\
\text { Interaction }\end{array}$ & $\begin{array}{l}(\mathrm{T})= \\
(\mathrm{C}) \\
(\mathrm{T} \times\end{array}$ & $\begin{array}{l}.479 \\
0.371 \\
=0.831\end{array}$ & & $\begin{array}{l}\text { Treatm } \\
\text { Cuts } \\
\text { Interac }\end{array}$ & (T & $\begin{array}{l}=0.354 \\
=0.274 \\
\text { C) }=0.615\end{array}$ & \\
\hline
\end{tabular}

3.1.3- Effect of organic and inorganic fertilizers on chemical composition of Sorghum cultivars:

Chemical composition was affected by application of organic and inorganic fertilizers are shown in Table (4), the values were ranged from 8.28 to $8.88 \%$ for protein content. The ash and fiber contents were ranged significantly from 10.24 to $10.66 \%$ for ash, while the values of crude fiber were between 31.32 to $32.78 \%$. $\mathrm{T}_{2}$ has given high value of both ash and fiber content in sorghum plants compared with other treatments. While in case of ether extract was ranged from 2.00 to $1.78 \%$. The results appeared that nitrogen free extracts value increased, its range was from $46.65 \%$ to $47.42 \%$. The calculated total digestible nutrients values ranged from 58.86 to $59.29 \%$.

The results showed that the total digestible nutrients values were affected by different application rates, where the $\mathrm{T}_{3}$ addition rate led to significant increase in plants compared with the other rats. These results almost agree with that obtained by Amandeep Saini, (2012) Amin et. al., (2012),
Abou-Amer and Kewan, (2014) and Almodares and Hadi (2009).

Mahmud et.al., (2003) reported that application of nitrogen led to increasing the crude protein and dry matter yield in forage sorghum. They also mentioned that good plant nutrition may not only affect the forage production but also improve the quality of forage from view point of its protein contents. Stevens, et.al, (1996) and McDonald et.al., (1991) reported that fiber content was decreased due to the application of nitrogen fertilizer. Application of nitrogen fertilizer led to decreasing soluble carbohydrates content in sorghum (Sumner, et.al., 1995). The nitrogen free extracts value in forage sorghum plants was significantly increased by using $\mathrm{T}_{5}$ than the other treatments. These results almost agree with that obtained by Khan et.al., (2008) and Amendeep Siani (2012). The integrated use of organic nutrient sources with inorganic fertilizer showed on increase and the potential of organic fertilizer (Heluf, 2002). Nitrogen fertilization plays an important role in improving the quality of fodder.

Table 4. Grand mean for chemical composition of forage Sorghum as affected by organic and mineral fertilizers on different levels during two seasons

\begin{tabular}{lcccccc}
\hline Treatment/ Chemical \% & CP & CF & EE & ASH & NFE & TDN \\
\hline $\mathbf{T}_{\mathbf{1}}(\mathbf{C 0 M 1 0 0 \% )}$ & 8.48 & 31.63 & 1.85 & 10.24 & 47.37 & 58.86 \\
\hline $\mathbf{T}_{\mathbf{2}}(\mathbf{C 6 M 0 )}$ & 8.34 & 32.78 & 1.98 & 10.66 & 46.65 & 59.10 \\
\hline $\mathbf{T}_{\mathbf{3}}(\mathbf{C 4 . 5 M 2 5 \% )}$ & 8.88 & 31.32 & 1.88 & 10.58 & 47.42 & 59.29 \\
\hline $\mathbf{T}_{\mathbf{4}}(\mathbf{C 3 M 5 0 \% )}$ & 8.28 & 32.34 & 1.78 & 10.53 & 47.04 & 58.99 \\
\hline $\mathbf{T}_{\mathbf{5}}(\mathbf{C 1 . 5 M 7 5 \% )}$ & 8.39 & 32.05 & 2.00 & 10.49 & 47.07 & 59.05 \\
\hline L.S.D. at 0.05 levels & 0.13 & 0.06 & 0.05 & 0.32 & 0.31 & 0.14 \\
\hline
\end{tabular}

3.1.4-Effect of organic and inorganic fertilizers on fiber fraction of sorghum cultivars:

Table (5) illustrate that the fiber fractions were significantly affected by using organic and inorganic fertilizers alone or combined. The results showed that the $\mathrm{T}_{2}$ addition rate led to non-significant increase values of NDF and ADF than the other treatments. The chemical fertilizer plus organic amendment have no-significant effect on Neutral
Detergent Fiber (NDF), Acid Detergent Fiber (ADF), and Acid Detergent Lignin (ADL), these results agreements with Pholson and Suksri (2004). Chaugool et. al. (2013) observed the results contents of neutral detergent fiber (NDF) ranged from 531 to $750 \mathrm{~g} \mathrm{Kg}^{-1} \mathrm{DM}$, acid detergent fiber (ADF) ranged from $250-411 \mathrm{~g} \mathrm{Kg}^{-1} \mathrm{DM}$, and acid detergent lignin (ADL) ranged from 41.8 to $75.4 \mathrm{~g} \mathrm{Kg}^{-1} \mathrm{DM}$. Amin $\boldsymbol{e t}$ al., (2012) reported that $\mathrm{ADF}$ was significantly 
affected by soil fertilizing systems $(\mathrm{p}<0.01)$ and has a reverse relation with chemical fertilizer. Muir (2002) reported that the application of compost led to increasing the NDF values.

Table 5. Grand mean for fiber fraction of forage Sorghum as affected by organic and mineral fertilizers on different levels during two seasons

\begin{tabular}{cccccc}
\hline Treatments & NDF \% & ADF\% & ADL \% & hemicellulose & cellulose \\
\hline $\mathbf{T}_{\mathbf{1}}(\mathbf{C 0 M 1 0 0 \% )}$ & 61.06 & 39.04 & 5.65 & 22.82 & 34.45 \\
$\mathbf{T}_{\mathbf{2}}=(\mathbf{C 6 M 0 )}$ & 61.61 & 39.23 & 5.94 & 22.29 & 33.59 \\
\hline $\mathbf{T}_{\mathbf{3}}(\mathbf{C 4 . 5 M 2 5 \% )}$ & 62.54 & 41.10 & 6.35 & 20.29 & 34.94 \\
\hline $\mathbf{T}_{\mathbf{4}}=\mathbf{C 3 M 5 0 \%}$ & 61.63 & 40.67 & 6.12 & 20.33 & 35.78 \\
\hline $\mathbf{T}_{\mathbf{5}}(\mathbf{C 1 . 5 M 7 5 \% )}$ & 61.68 & 39.91 & 5.83 & 22.04 & 34.17 \\
\hline L.S.D. at 0.05 levels & 0.185 & 0.150 & 0.116 & 0.243 & 0.212 \\
\hline
\end{tabular}

Neutral Detergent Fiber (NDF \%), Acid Detergent Fiber (ADF \%), Acid Detergent Lignin (ADF\%)

3.1.5- Effect of organic and inorganic fertilizers on In-vitro ruminal gas production of sorghum cultivar:

Data in table (6) indicated that different addition rates of compost and mineral fertilizers affected the content of Gas production insoluble fraction (GPNSF), Gas production soluble fraction (GPSF) and Gas production correct (GP) during incubation period, where it ranged from 44.55 to $60.99 \%$ for (GPNSF) and from 8.14 to $15.65 \%$ in for (GPSF), while in case of (GP) it ranged from 20.20 to 32.18 $\mathrm{ml} / 200 \mathrm{mg}$. Regarding to the cuts of sorghum plant, it was found that $1^{\text {st }} \mathrm{Cut}$ of both (GPISF) and (GP) was more than other cuts, while in case of (GPSF) the $3^{\text {rd }}$ Cut was the best. As for the interaction between addition rates and cutes, it was found that the $T_{2}$ application rates at $1^{\text {st }}$ Cut gave highest values of both (GPNSF) and (GP) compared with other treatments, while the (GPSF) values was increased with using $\mathrm{T}_{4}$ at $3^{\text {rd }}$ Cut better than others. Indicating that different addition rates of compost and mineral fertilizers affected the content of (GPISF), (GPSF) and (GP) during incubation period. It is clear from the gas parameters values increased with using deferent rates of organic only or combined with minerals compared with control. It was found that using of $\mathrm{T}_{2}$ application rate gave high values compared with the other treatments of (GPNSF), (GPSF) and (GP) during incubation period. The results showed that the (GPNSF) values of forage Sorghum plant significantly increased by using organic alone or combined with mineral fertilizers.

The integrated use of organic nutrient sources with inorganic fertilizer was shown to increase the potential of organic fertilizer (Heluf, 2002). Application of mineral nutrient becomes essential to satisfy nutrient uptake. It is universally accepted that the use of mineral fertilizers is an integral part of practices for increasing the agricultural production (Poudel et al., 2001). Nitrogen fertilization plays an important role in improving the quality of fodder. Being an exhaustive crop, quality of sorghum fodder suffers heavily if proper amount of fertilizer is not applied (Muldoon, 1985). While El- Sherief et al (2013) found that the applications of the compost $+75 \mathrm{~kg} \mathrm{~N} /$ fed led to increasing vegetative and forage yield parameters of Sudan grass during the two seasons.

Table 6. Gas production parameters of different cuts of forage Sorghum Cultivars as affected by organic and mineral treatments

\begin{tabular}{|c|c|c|c|c|c|c|c|c|c|c|c|c|}
\hline \multirow[b]{2}{*}{ Treatments } & \multicolumn{3}{|c|}{ GP (ml/200mg) } & \multirow[b]{2}{*}{ Means } & \multicolumn{3}{|c|}{ GPSF (\%) } & \multirow[b]{2}{*}{ Means } & \multicolumn{3}{|c|}{ GPNSF (\%) } & \multirow[b]{2}{*}{ Means } \\
\hline & $\begin{array}{l}1^{\text {st. }} \\
\text { Cut }\end{array}$ & $\begin{array}{l}2^{\text {nd }} \\
\text { Cut }\end{array}$ & $\begin{array}{c}3^{\text {rd }} \\
\text { Cut }\end{array}$ & & $\begin{array}{l}1^{\text {st. }} \\
\text { Cut }\end{array}$ & $\begin{array}{l}2^{\text {nd }} \\
\text { Cut }\end{array}$ & $\begin{array}{c}3^{\text {rd }} \\
\text { Cut }\end{array}$ & & $\begin{array}{l}1^{\text {st. }} \\
\text { Cut }\end{array}$ & $\begin{array}{l}2^{\text {nd }} \\
\text { Cut }\end{array}$ & $\begin{array}{c}3^{\text {rd }} \\
\text { Cut }\end{array}$ & \\
\hline $\mathrm{T}_{1}(\mathrm{C0M100 \%})$ & 21.70 & 25.32 & 24.13 & 23.72 & 10.01 & 8.80 & 9.953 & 9.597 & 53.10 & 54.91 & 52.16 & 53.39 \\
\hline$T_{2}=($ C6M0 $)$ & 32.18 & 26.07 & 25.52 & 27.923 & 15.65 & 12.51 & 8.88 & 12.35 & 60.99 & 55.91 & 56.00 & 57.63 \\
\hline $\mathrm{T}_{3}(\mathrm{C} 4.5 \mathrm{M} 25 \%)$ & 20.20 & 21.21 & 21.28 & 20.89 & 13.83 & 8.88 & 11.19 & 11.30 & 44.55 & 45.32 & 50.50 & 46.79 \\
\hline $\mathrm{T}_{4}=\mathrm{C} 3 \mathrm{M50} \%$ & 27.14 & 22.63 & 27.49 & 25.75 & 11.85 & 8.14 & 16.82 & 12.27 & 57.55 & 54.71 & 56.51 & 56.25 \\
\hline $\mathbf{T}_{5}=(\mathrm{C} 1.5 \mathrm{M} 75 \%)$ & 26.71 & 25.24 & 21.79 & 24.58 & 8.88 & 8.39 & 13.91 & 10.39 & 50.28 & 50.75 & 45.44 & 48.82 \\
\hline $\begin{array}{c}\text { L.S.D. at } 0.05 \\
\text { levels }\end{array}$ & & $\begin{array}{l}\text { atment } \\
\text { Cuts (C } \\
\text { action }\end{array}$ & $\begin{array}{l}\text { T) }=0 \\
=1.05 \\
\times C)=\end{array}$ & $\begin{array}{l}15 \\
821\end{array}$ & & $\begin{array}{l}\text { atment } \\
\text { Cuts ( } \\
\text { raction }\end{array}$ & $\begin{array}{l}T)= \\
=0.95 \\
\Gamma \times C)=\end{array}$ & $\begin{array}{l}34 \\
138\end{array}$ & & $\begin{array}{l}\text { atments } \\
\text { Cuts (C } \\
\text { action }\end{array}$ & $\begin{array}{l}\mathrm{T})= \\
=1.19 \\
\times \mathrm{C})=\end{array}$ & $\begin{array}{l}546 \\
.678\end{array}$ \\
\hline
\end{tabular}

$\mathrm{GP}=$ Correct Gas Production, GPSF=Gas Production Structure Fiber, GPNSF=Gas Production Non-Structure Fiber

The effect of organic and inorganic fertilizer on metabolic energy (ME), net energy lactation (NEL) and short chain fatty acid SCFA,s was recorded in Table (7). Concerning the effect of treatments on 
metabolic energy; net energy lactation and short chain fatty values ranged from 4.99 to $6.13,2.47$ to $4.36 \mathrm{MJ} / \mathrm{Kg} \mathrm{DM}$ and 0.53 to $0.79 \mathrm{~m} \mathrm{~mol} / \mathrm{ml}$ gas respectively. It was found that using of $\mathrm{T}_{2}$ application rate gave significant high values compared with the other treatments of metabolic energy, net energy lactation and short chain fatty acid during incubation period.

Regarding to the cuts of sorghum plant, it was noticed that $1^{\text {st }}$ Cut of both NEL and SCFA, s was better than the other cuts, while in case of ME the $2^{\text {nd }}$ Cut was the best. With respect to the interaction between addition rates and cuts, the results showed that the ME, NEL and SCFA, s of sorghum plant significantly increased, it was found that the $T_{2}$ application rates at $1^{\text {st }} \mathrm{Cut}$ gave the highest values of both NEL and SCFA, s compared with the other treatments, while the ME values were increased with using $\mathrm{T}_{2}(\mathrm{C} 6 \mathrm{M} 0)$ at $3^{\text {rd }}$ Cut better than the others. Similar results were reported by Peyraud et. al., (1997) and Kumar et. al.,(2015). The effect of organic and inorganic manure on $\mathrm{DMD}_{\mathrm{iv}}$ and $\mathrm{OMD}_{\mathrm{iv}}$ was recorded in Table (8). Concerning the effect of treatments on dry matter digestibility and organic matter digestibility the values ranged from 54.70 to 74.46 and 48.63 to $56.98 \%$, respectively. It was found that using of $\mathrm{T}_{4}$ application rate gave significant high values compared with the other treatments in both DMD and OMD in $3^{\text {rd }}$ cut, while the highest value in $2^{\text {nd }}$ cut of DMD on C0M100\% and OMD on $\mathrm{T}_{2}$. As for the rate, the results appeared that nutritional values increased with using different rates of organic only or combined with minerals compared with control. It was found that using of $\mathrm{T}_{3}$ application rate gave significant high values of dry matter digestibility compared with other treatments, while in case organic matter digestibility $\mathrm{T}_{2}$ addition rate was the best by Chaugool et al. (2013) and Kumar et al., (2015). On the other hand, Pholson and Suksri (2004) showed that the application of chemical fertilizer plus organic amendment have nosignificant effect on dry matter digestibility.
Regarding to the cuts of sorghum plant, it was noticed that $1^{\text {st }}$ Cut of both DMD and OMD were better than other cuts. With respect to the interaction between of addition rates and cutes, the results showed that the DMD and OMD values of sorghum plant significantly increased by using organic alone or combined with mineral fertilizers, it was found that the $T_{2}$ application rates at $1^{\text {st }}$ Cut gave the highest values of DMD and OMD compared with the other treatments. Similar results were reached by Chaugool et.al., (2013), Kumar et.al., (2015). On the other hand, Pholsonand and Suksri (2004) showed that the application of chemical fertilizer plus organic amendment have no-significant effect dry matter digestibility. Reading metabolic energy, it has been observed from data that there was no significant $(p>0.05)$ differences among the treatments. However, increasing rate of IVOMD resulted due to the nitrogen treatment. Out of five levels showed higher IVOMD in all stages of maturity. Similar results were also observed by Malak (2005) and Pervin (2004) working on German grass. Johnson et.al., (2001) reported that applying different doses of $\mathrm{N}$ fertilizer on Star grass and Bermuda grass linearly led to increasing IVOMD of both grasses. Finally, we could conclude that the $\mathrm{T} 2=100 \%$ organic fertilizer is considered the best treatment in terms of feeding the animal and the size of the crop in the second cut is like the size of the crop in the third cut of the $\mathrm{T}_{4}$, which gave the best economic feasibility of fourth treatment but using the second cut of the second treatment to provide the time of cultivation for another crop. In addition, necessary work of the digestion and feeding trails on the animal on these second cut of $\mathrm{T} 2$, which gave positive results in order to link the amount of yield in the first and second cut and digestion factors and measure the amount of meat produced to determine the economic efficiency in obtaining a good crop of quantity and quality and reduce the crop period to provide more land for cultivation with another crop as well as reducing the mineral contamination of the water- table.

Table 7. Energy parameters and Short chain fatty acid of forage Sorghum as Affected by organic and mineral treatments in the tested soil

\begin{tabular}{|c|c|c|c|c|c|c|c|c|c|c|c|c|}
\hline \multirow[b]{2}{*}{ Treatments } & \multicolumn{3}{|c|}{$\begin{array}{c}\text { (ME) MJ/Kg } \\
\text { DM }\end{array}$} & \multirow{2}{*}{ Means } & \multicolumn{3}{|c|}{$\begin{array}{c}\text { (NEL) JM/ kg } \\
\text { DM }\end{array}$} & \multirow{2}{*}{ Means } & \multicolumn{3}{|c|}{$\begin{array}{c}\text { (SCFA) m mol/ml } \\
\text { gas }\end{array}$} & \multirow{2}{*}{ Means } \\
\hline & $\begin{array}{l}1 \text { st. } \\
\text { Cut }\end{array}$ & $\begin{array}{l}2^{\text {nd }} \\
\text { Cut }\end{array}$ & $\begin{array}{c}3^{\text {rd }} \\
\text { Cut }\end{array}$ & & $\begin{array}{l}1 \text { st. } \\
\text { Cut }\end{array}$ & $\begin{array}{c}2^{\text {nd }} \\
\text { Cut }\end{array}$ & $\begin{array}{l}3^{\text {rd }} \\
\text { Cut }\end{array}$ & & 1 st. & $\begin{array}{l}2^{\text {nd }} \\
\text { Cut }\end{array}$ & $\begin{array}{l}\mathbf{3}^{\text {rd }} \\
\text { Cut } \\
\end{array}$ & \\
\hline $\begin{array}{c}\mathrm{T}_{1} \\
(\mathrm{C} 0 \mathrm{M} 100 \%)\end{array}$ & 5.26 & 5.58 & 5.39 & 5.41 & 2.68 & 2.95 & 2.78 & 2.80 & 0.583 & 0.633 & 0.610 & 0.609 \\
\hline$T_{2}=($ C6M0) & 13 & 5.76 & 5.45 & & 34 & 3.05 & 2.8 & & 87 & 0.667 & 06 & 0.69 \\
\hline $\mathbf{T}_{3}\left(\mathbf{C}_{4}\right.$ & 99 & 5.02 & 5.1 & 4.98 & 49 & 2.47 & 2.6 & 2.5 & 33 & 0.547 & & \\
\hline$T_{4}=($ & 70 & 5.33 & 5.8 & & 1 & 2.78 & 3. & & 0.663 & 0. & 0 & \\
\hline & 5.26 & 5.23 & 5.10 & 5.20 & 4.36 & 2.67 & 2.70 & 3.24 & 0.617 & 0.583 & 0.560 & 0.587 \\
\hline $\begin{array}{l}\text { L.S.D. at } 0.05 \\
\text { levels }\end{array}$ & \multicolumn{4}{|c|}{$\begin{array}{l}\text { Treatments }(T)=0.183 \\
\text { Cuts }(C)=0.142 \\
\text { Interaction }(T \times C)=0.317\end{array}$} & \multicolumn{4}{|c|}{$\begin{array}{l}\text { Treatments }(T)=0.167 \\
\text { Cuts }(C)=0.129 \\
\text { Interaction }(T \times C)=0.289\end{array}$} & \multicolumn{4}{|c|}{$\begin{array}{l}\text { Treatments }(T)=0.0300 \\
\text { Cuts }(C)=0.0233 \\
\text { Interaction }(T \times C)=0.0520\end{array}$} \\
\hline
\end{tabular}


$\mathrm{ME}(\mathrm{MJ} / \mathrm{Kg} \mathrm{DM})=$ Metabolic energy, NEL $(\mathrm{MJ} / \mathrm{Kg} \mathrm{DM})=$ Net Energy Lactation, SCFA $(\mathrm{m} \mathrm{mol} / \mathrm{ml}$ gas $)=$ Short Chain Fatty Acid

Table 8. Dry matter Digestibility and Organic Matter Digestibility of forage Sorghum as affected by organic and mineral treatments in the tested soil.

\begin{tabular}{|c|c|c|c|c|c|c|c|c|}
\hline \multirow{2}{*}{ Treatments } & \multicolumn{3}{|c|}{ DMD \% } & \multirow{2}{*}{ Means } & \multicolumn{3}{|c|}{ OMD \% } & \multirow{2}{*}{ Means } \\
\hline & 1 st. Cut & $2^{\text {nd }} \mathrm{Cut}$ & $3^{\text {rd }}$ Cut & & 1 st. Cut & $2^{\text {nd }} \mathrm{Cut}$ & $3^{\text {rd }}$ Cut & \\
\hline $\mathrm{T}_{1}(\mathrm{C} 0 \mathrm{M100 \%})$ & 63.59 & 70.80 & 66.10 & 66.83 & 52.28 & 52.46 & 50.90 & 51.88 \\
\hline$T_{2}=($ C6M0 $)$ & 74.46 & 59.56 & 61.31 & 65.11 & 56.98 & 53.88 & 52.41 & 54.41 \\
\hline $\mathrm{T}_{3}(\mathrm{C} 4.5 \mathrm{M} 25 \%)$ & 74.16 & 63.50 & 63.32 & 66.99 & 54.45 & 48.63 & 49.24 & 50.77 \\
\hline $\mathrm{T}_{4}=\mathbf{C} 3 \mathrm{M50} \%$ & 65.27 & 54.70 & 69.21 & 63.06 & 52.53 & 50.55 & 53.43 & 52.17 \\
\hline $\mathbf{T}_{5}=(\mathrm{C} 1.5 \mathrm{M} 75 \%)$ & 66.42 & 61.15 & 63.39 & 63.65 & 50.28 & 51.66 & 50.14 & 51.05 \\
\hline $\begin{array}{l}\text { L.S.D. at } 0.05 \\
\text { levels }\end{array}$ & $\begin{array}{l}\text { Treatments } \\
\text { Cuts } \\
\text { Interaction }\end{array}$ & $\begin{array}{l}(\mathrm{T})= \\
(\mathrm{C})= \\
(\mathrm{T} \times \mathrm{C})\end{array}$ & $\begin{array}{l}1.483 \\
.49 \\
=2.569\end{array}$ & & $\begin{array}{l}\text { Treatmer } \\
\text { Cuts } \\
\text { Interactic }\end{array}$ & $\begin{array}{l}\text { (T) } \\
\text { (C } \\
\text { (T) }\end{array}$ & $\begin{array}{l}=0.995 \\
=0.7708 \\
=1.724\end{array}$ & \\
\hline
\end{tabular}

$\mathrm{DMD}=$ Dry matter digestibility $\quad$ OMD =Organic matter digestibility

\subsection{6-Economic evaluation:}

3.1.6.1- Costs: Total costs including values of production tools and requirements such as seeds, fertilizers, irrigation, man power, machinery and other general or miscellaneous costs without land rent average during summer seasons 2013 and 2014 are shown in Table (9).The price of 50 kilogram ammonium nitrate $(33.5 \% \mathrm{~N})$ was 70 L.E., the price of 50 kilogram calcium super phosphate $(15.5 \%$ P2O5) was 55 L.E., and the price of 50 kilogram potassium Sulphate (48\% K2O) was 200 L.E., the price of one kilogram seeds was $15 \mathrm{~L}$.E. the total cost of soil tillage included the cost for first and second plowing by chisel plow was 200 L.E. are present in Table (9).Data in Table (9) show the total costs of forage sorghum production per feddan as affected by applying different treatments (average of 2013 and 2014 seasons). From such data, the minimum total costs were those of application of control (nitrogen fertilizer $100 \% \mathrm{~N}$ ), being 2820 L.E. and the maximum total costs were those of the plants received the recommended compost rate (100\%).which was 3380 L.E. Average over all treatments of total costs were 3350 L.E.

Table 9. Estimated net return L.E.fed -1 of forage Sorghum treated with mineral and organic under different nitrogen levels over the two seasons of 2014-2015.

\begin{tabular}{|c|c|c|c|c|c|}
\hline $\begin{array}{c}\text { Treatments } \\
\text { Cost of production inputs }\end{array}$ & $\begin{array}{c}\mathbf{T}_{1} \\
(100 \% \\
\mathrm{N})\end{array}$ & $\begin{array}{c}\mathrm{T}_{2} \\
\text { (compost } \\
100 \%) \\
\end{array}$ & $\begin{array}{c}\mathrm{T}_{3} \\
(25 \% \mathrm{~N} \text { and } \\
\text { compost } 75 \%)\end{array}$ & $\begin{array}{l}\quad \mathbf{T}_{4} \\
(\mathbf{5 0 \%} \text { and } \\
\text { compost } 50 \%)\end{array}$ & $\begin{array}{l}\mathrm{T}_{5} \\
(\mathbf{7 5} \% \mathrm{~N} \text { and } \\
\text { compost } 25 \%) \\
\end{array}$ \\
\hline \multicolumn{6}{|l|}{ land preparation } \\
\hline$\overline{\text { Tillage }}$ & 200 & 200 & 200 & 200 & 200 \\
\hline Planting & 300 & 300 & 300 & 300 & 300 \\
\hline Seeds & 300 & 300 & 300 & 300 & 300 \\
\hline Irrigation & 600 & 600 & 600 & 600 & 600 \\
\hline Mineral fertilization & & & & & \\
\hline \multirow{6}{*}{$\begin{array}{l}\text { Ammonium nitrate }(33.5 \% \\
\text { N) Compost } \\
\text { Super phosphate }(15.5 \% \\
\left.\mathbf{P}_{2} \mathrm{O}\right) \\
\text { Potassium sulphate }(\mathbf{4 8} \% \\
\left.\mathrm{K}_{2} \mathrm{O}\right) \\
\text { HoeingHarvesting }\end{array}$} & 140 & - & 35 & 70 & 105 \\
\hline & - & 1200 & 900 & 600 & 300 \\
\hline & 400 & 400 & 400 & 400 & 400 \\
\hline & 200 & 200 & 200 & 200 & 200 \\
\hline & 80 & 80 & 80 & 80 & 80 \\
\hline & 600 & 600 & 600 & 600 & 600 \\
\hline Total variable cost & 2820 & 3880 & 3615 & 3350 & 3085 \\
\hline Yield ton fed $^{-1}$ & 72.14 & 75.26 & 79.42 & 77.46 & 76.60 \\
\hline Price ton $^{-1}$ & 150 & 150 & 150 & 150 & 150 \\
\hline Total revenue & 10521 & 11289 & 11913 & 11619 & 1490 \\
\hline Net return & 7701 & 7409 & 8298 & 8269 & 8405 \\
\hline Return of investedL.E. & 3.73 & 2.90 & 3.29 & 3.46 & 3.72 \\
\hline Net return of invested L.E. & 2.73 & 1.90 & 2.29 & 2.46 & 2.72 \\
\hline Net return $\left(\right.$ L.E.fed. $\left.{ }^{-1}\right)=$ Total & $T$ & De & 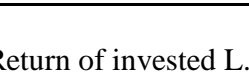 & $=\frac{\text { Talial revemue }}{\text { Tolal (variable) cost }}$ & \\
\hline
\end{tabular}


3.1.6.2-Net return: Results in Table (9) reveal that the highest net farm return was achieved from treatment $\mathrm{C} 1.5 \mathrm{M} 75 \%$ combined with $75 \%$ organic $+25 \% \mathrm{~N}$ fertilization (8405 L.E.fed-1) followed by the compost rate $75 \%$ with $\mathrm{N} 25 \%$ (8298 L.E.fed-1) and the recommended N 50\% with C3 100\% (8268 L.E. fed. -1). On the other hand, the lowest net farm return was (7409 L.E.fed-1) recorded by nitrogen fertilizer (100\% organic). But, the highest net return per one invested L.E. was achieved from $100 \% \mathrm{~N}$ fertilization (2.73 L.E.) and application C1.5 N $75 \%$ (2.72 L.E.) Followed by application C $3+50 \% \mathrm{~N}$ fertilization (2.29 L.E.fed-1) and the recommended nitrogen rate $25 \%$ and compost $75 \%$ (2.29 L.E.), followed by the lowest net return of investment $(1.90$ L.E.) which recorded for compost $100 \%$.

\section{Conclusion}

This study aimed to study the effect of organic manure alone, chemical composition and plant digestibility. Generally, most yield components like, plant height, fresh weight, dry weight and protein contents here been increased with applying fertilizer. The effect of interaction between compost and nitrogen fertilizers showed a significant effect on all characters and its components under study, it is obvious from the result that forage sweet Sorghum cultivar fertilized with compost and nitrogen fertilizer gave the highest values for most characters under study especially compost and M25\% treatment.

\section{References}

Abou-Amer, A. I. and Kewan K. Z. (2014) Effect of NP Fertilization Levels on Sorghum (Sorghum bicolor L.) Yield and Fodder Quality for Animals. Alex. J. Agric. Res.

Ahmad, R., Arshad M., Naveed, M., Zahir Z.A., Sultan,T. and Khalid, M. (2009) Carbon mineralization rate of composted and raw organic wastes and their implications on environment Soil \& Environ., 26: 92-96.

Almodares, A. and Hadi, M. (2009) Production of bioethanol from sweet sorghum: A review. African Journal of Agricultural Research, 4 (9): 772-780.

Amandeep saini (2012) Forage quality of sorghum (Sorghum Bicolor L.) as influenced by irrigation, nitrogen levels and harvesting stage. Indian J.Sci.Res.3 (2): 67-72.

Amin Sedaghat, Sasan Siahkouhian, Gholam Abbas Akbari and Ebrahim Sharifi Ashour Abadi (2012). Investigation of different soil fertilizing systems on forage yield and quality of Sorghum (Sorghum bicolor (L.) moench). Int. J. of Bios. | IJB | ISSN: 2220-6655 (Print) 2222-5234 (Online), Vol. 3, No. 10, p. 170-179.
AOAC (2000) Official Methods of Analysis, 15th edn. Association of Official Analytical Chemists. Washington DC, USA.

Ashiono, G.B., Gatuiku, S., Mwangi, P. and Akuja, T.E. (2005) Effect of nitrogen and phosphorus application on growth and yield of dual - purpose sorghum (Sorghum bicolor (L.) moench), E1291, in the dry highlands of Kenya. Asian J. Plant Sci., 4:379-382.

Aspasia Efthimiadou, Dimitrios Bilalis, Anestis Karkanis and Bob Froud-Williams (2010) Combined organic/inorganic fertilization enhance soil quality and increased yield, photosynthesis and sustainability of sweet maize crop. AJCS 4(9):722-729.

Babayemi OJ (2007). In-Vitro fermentation characteristics and acceptability by West African dwarf goats of some dry season forages. Afr. J. Biotechnology. 6:1260-1265.

Basak, R. K. (2006): "Fertilizers". Kalyani Publishers, Ludhiana - New Delhi Noida (U. P.) Hyderabad - Chennai - Calcutta - Cuttack.

Blummel, M. and Orskov, E.R. (1993). Comparison of gas production and nylon bag degradability of roughages in predictions feed intake in cattle. Anim. Feed Sci. Techno, 40:109.

Brunner, P.H. and Wasmer, H.R. (1978) "Methods of analysis of sewage sludge solid wastes and compost". W.H.O. Inter. Reference Cen. for Wastes Disposal (H-8600), Dulendr of Switzerland.

Buxton, D. R.; Anderson, I. C. and Hallam, A. (1999). Performance of sweet and forage sorghum grown continuously double cropped with winter rye, or in rotation with soybean and maize. Agro. j. 91, 93-101.

Chaugool Jiraporn, Makoto Kondo and Shigem (2013) ruminant using in vitro gas production technique. Pak. J. Nutr. 4: 298-303. Nutritional evaluation and in vitro ruminal fermentation of Sorghum cultivars. Journal of Food, Agri. \& Environment Vol.11 (2): 345-351.

Chumpawadee S, Sommart K, Vongpralub $\mathrm{T}$ and Pattarajinda V (2005). Nutritional evaluation of non-forage high fibrous tropical feeds for ruminant using in vitro gas production technique. Pak. J. Nutr. 4: 298-303.

Cottenie, M., Verloo, L., Kieken, G., Velgh and Camcrlynck, R. (1982) Chemical Analysis of Plant and Soil. Lab. Anal. Agro. Chem., State Univ., Ghent, Belgim.

El-Sabbagh, A.A. (2001) Forage sorghum production as influenced by soil moisture stress and nitrogen fertilizer. Minufiya J.Ageic.Res., 26 [5]:10; 104 $-241$.

El-Sherief, A. A.; Manal, F. A. T. and Shaban, Kh, A. (2013). Improving newly reclaimed sandy soil properties and its productivity of Sudan grass by organic, bio and mineral $-\mathrm{N}$ fertilization. The 
Second International Conference on Environmental studies and research (Natural Resources \& Future Challenges), Environmental Studies and Research Institute (ESRI), University of Sadat City, Egypt, 25-27 February 2013, pp. 249-266.

Farhad, W., Saleem, M. F., Cheema, M. A. and Hammad, H. M. (2009) Effect of poultry levels on the productivity of spring Maize (Zea mays L.). The J of Ani. \& Plant Sci. 19(3), P:122-125 ISSN: 1018-7081.

Getachew G, Robinson PH, De-Peters EJ and Taylor SJ (2004). Relationships between chemical composition, dry matter degradation and in vitro gas production of several ruminant feeds. Anim. Feed Sci. Tech. 111: 57-71.

Ghosh, P.K., Ramesh, P., Bandyopadhyay, K.K., Hati, K.M. and Misra, A.K. (2004) Comparative effectiveness of cattle manure, poultry manure, phosphor, compost and fertilizer-NPK on three cropping systems in verticals of semi-arid tropics. Crop yield and system performance. Bio resource Technology 95, 77-83.

Gheit,G.S., EI-Shahawy, A.E. and Abd El-Gawad, M.A.S. (1999) Effect of nitrogen sources and aplite application on forage yield and its quality in sorghum. J. Agric. Sci. Man. Univ., 24[8]:3761-3768.

Gomez, K.A. and Gomez, A.A. (1984). Statistical Procedures for Agri. Res., 2nd ed., Wiley, New York.

Gupta P.C. and Pradhan K. (1995) Variability of protein, cell wall constituents, and in vitro nutrient digestibility in some strain of fodder oat harvested at different stages of growth. Ind. J. of Agri. Sci. 46, 359 - 362.

Han KJ, Pitman WD, Kim M, Day DF, Alison MW, McCormick ME and Aita G. (2013) Ethanol production potential of sweet sorghum assessed using forage fiber analysis procedures. Global Change Biology Bioenergy, 5,358 - 36.

Hanan S. Siam, M.R. Abd El-Moez and S.M. ElashryIqbal, A., Iqbal, M.A., Raza, A., Akbar, N. and Abbas, R.N. (2014) Effect on yield and quality of maize fodder. M.Sc. and H.Z. Khan, 2014. Integrated nitrogen (Hons.) Thesis, Dept. Agron. Univ. Agric. management studies in forage maize. American- Faisalabad, Pakistan. Eurasian J. of Agric \& .Environ. Sci., 14(8): 744747.

Heluf, G. (2002) Soil and water Management Research Program Summary Report of 2000/2001 Research Activities, Alemaya University.

Iqbal Asif, Muhammad Aamir Iqbal, Faisal Nabeel, Haroon Zaman Khan, NadeemAkbar and Rana Nadeem Abbas (2014). Economic and Sustainable Forage Oat (Avena sativa L.) Production as Influenced by Different Sowing Techniques and Sources of Nitrogen.
Jaime, A. and Viola, P. (2011). The Effect of Compost and Inorganic Fertilizer Application on Baby Corn Performance. African Conference Proceedings, 10: 617- 619.

Johnson, C.R., Reiling, B.A., Mislevy, P. and Hall, M.B. (2001) Effect of nitrogen fertilization and harvest date on yield, digestibility, fiber and protein fractions of tropical grasses. J. Anim. Sci. 79: 2439-2446.

Kamalak, A., and Canbolat, O. (2010). Determination of nutritive value of wild narrowleaved clover (Trifolium angustifolium) hay harvested at three maturity stages using chemical composition and in vitro gas production. Trop. Grassland, 44: 128-133.

Kanak, A.R., Khan, M.J., Debi, M.R., Pikar, M.K. \& Aktar, M., (2012). Nutritive value of three fodder species at different stages of maturity. Bangladesh J. Anim. Sci. 41 (2):90-95.

Khaled, A. Shaban; Mona, G. Abd El-Kader and Seham, M. El-Khadrawy (2011) Evaluation of organic farm and compost combined with urea fertilizers on fertility and maize productivity in newly reclaimed. Res. J. of Agri. and Bio. Sci., 7(5): 388-397, 2011 ISSN 1816-1561.

Khan, M. J., Hannan, M. A. and Islam M. N. (2008) Effects of different nitrogen sources on yield, chemical composition and nutritive value of Dal grass (Hymenachne amplexicaulis) The Bangladesh Veterinarian 25(2): 75 - 81

Kramer, A.W., Timothy, A.D., Horwath, W.R. and Kassel, C.V. (2002) Combining fertilizer and organic input to synchronize $\mathrm{N}$ supply in alternative cropping systems in California. Agriculture Ecosystem \& Environment 91, 233243

Kumar Arun T. V., Samuel, D. V. K., Jha. S. K., and Sinha J. P. (2015) Twin Screw Extrusion of Sorghum and Soya Blends: A Response Surface Analysis. J. Agr. Sci. Tech. Vol. 17: 649-662.

Maheri -Sis N, Chamani M, Sadeghi AA, MirzaAghazadeh A and Aghajanzadeh-Golshani A (2008). Nutritional evaluation of kabuli and desi type chickpeas (Cicer arietinum L.) for ruminants using in vitro gas production technique. Afr. J. Biotechnol. 7: 2946-2951.

Maheri-Sis N, Chamani M, Sadeghi AA, MirzaAghazadeh A and Safaei AA (2007). Nutritional evaluation of chickpeas waste for ruminants using in vitro gas production technique. J. Anim. Vet. Adv. 6:1453-1457.

Mahmud, K., I. Ahmad and M. Ayub, (2003) Effect of Nitrogen and Phosphorus on the Effect of Nitrogen and Phosphorus (Sorghum bicolor L.). International Journal Agriculture Biology, 5: 6163.

Mahmood, A., Habib Ullah, Shahzad, A.N., ALI, H., Ahmad, S., ZIA-UL-HAQ, M., Honermeier, B. and Hasanuzzaman, M. (2013) Dry Matter Yield and Chemical Composition of Sorghum Cultivars 
with Varying Planting Density and Sowing Date. Sains Malaysiana 42(10): 1529-1538.

Malak (2005). Effect different levels of nitrogen and phosphorus on biomass yield, chemical composition and nutritive value of German grass at two stage of maturity. MS thesis. Department of Animal Nutrition, Bang. Agri. Univ., Mymensingh.

McDonald, P., A.R. Henderson and S.J.E. Heron, (1991). The Biochemistry of Silage. Chalcomepubl, Marlow, UK.

Menke, K.H., Raab, L., Salewaski, A., Steingass, H., Fritz, D. and Schnerider, W. (1979) The estimation of digestibility and metabolizable energy content of ruminant feedstuffs from the gas production when they are incubated with rumen liquor in vitro. J. Agric. Sci. 93: 217-222.

Menke, K.H. and Steingass, H. (1988) Estimation of energetic feed value obtain from chemical analysis and in vitro gas production using rumen fluid Anim. Res. Dev. 28: 7-55.

Mohamed M. Hussein, and Ashok K. Alva (2014) Growth, Yield and Water Use Efficiency of Forage Sorghum as Affected by Npk Fertilizer and Deficit Irrigation. American J. of Plant Sciences, 5, 2134-2140.

Mubarak, A. R.; Nazar, O.S.; Ali, A. H.; and Ahmed, G. M. (2007) Effect of application of organic amendments on quality of forage sorghum (sorghum bicolor L.) in the semi - arid tropics. Archives of Agronomy and Soil Science, 53(5) : $529-538$.

Muldoon D. K., (1985). The effect of nitrogen fertilizer on the growth, mineral composition and digestibility of a sorghum cross sudan grass hybrid and Japanese Barnyard Millet. Australian J. Exp. Agric., 25: 411-416.

Muir, J.P. (2002) Effect of Dairy Compost Application and Plant Maturity on forage Kenaf Cultivar Fiber Concentration and in Sacco Disappearance. Crop Science, 42: 248-254. Muldoon D. K., (1985). The effect of nitrogen fertilizer on the growth, mineral composition and digestibility of a sorghum cross sudan grass hybrid and Japanese Barnyard Millet. Australian J. Exp. Agric., 25: 411-416

Naga, M. A. and El-Shazly, K. (1971) The Prediction of the Nutritive Value of Animal Feeds from Chemical Analyses. J. agric. Sci., Camb., 77, 2531.

NARO (2009). Standard Tables of Feed Composition in Japan. National Agriculture and Food Research Organization, Japan Livestock Industry Association, pp. 37-38.

Nasef, M.A., Shaban, Kh.A. and Abdel Hameed, A.F. (2009) Effect of compost and bio-fertilizer application on some chemical soil properties and rice productivity under saline soil condition. J. Agric. Mansoura Univ.,
Orskov, E.R. (1998). Feed evaluation with emphasis on fibrous roughages and fluctuating supply of nutrients: a review. Small Ruminant Research. 28: $1-8$.

Oliver, A. L., Grant, R. J., Pedersen, J. F. and O'Rear, J. (2004). Comparison of brown midrib-6 and -18 forage sorghum with conventional sorghum and corn silage in diets of lactating dairy cows. J. Dairy Sci. 87:637- 644. 34 (4): 2609- 2623.

Page, C.A., Evans, D.D., White, J.L., Ensiminger, L.E. and Clark, F.E. (1982) Methods of Soil Analysis. Amer. Soc. Agron. Inc., Ser. 9 in Agron. Madison, Wisconsin.

Pervin (2004). Effect of different doses of nitrogen and phosphorus fertilizer on yield, chemical composition and nutritive value of German grass. M.S. thesis. Department of Animal Nutrition, Bang. Agri. Univ., Mymensingh, Bangladesh.

Peyraud, J.L., Astigarraga, L. and Favendin, P. (1997) Digestion of fresh perennial ryegrass fertilized at two levels of nitrogen by lactating dairy cows. Animal Science and Technology 64 155-171.

Pholsen S. and Suksri A. (2004) Effect of Organic Amendment and Chemical fertilizer on Growth, Yield and Fodder Quality of a Forage Sorghum (Sorghum bicolor (L.) moench). Pakistan Journal of Biological Sciences 7 (4): 651-657

Poudel D.D., WR Horwath, JP Mitchell, SR Temple (2001). Impacts of cropping systems on soil nitrogen storage and loss- Elsevier Agricultural Systems science direct Volume 68, Issue 3, June 2001, Pages 253-268

Roy, P. R. S. and Khandaker, Z. H. (2010) Effect of phosphorus fertilizer on yield and nutritional value of sorghum (Sorghum bicolor L.) fodder at three cuttings. Bang. J. Anim. Sci., 39(1\&2): 106 $-115$

Sallam S.M. A.; Nasser M.E.A.; El-waziry, A.M; Bueno F.C.S. and Abdallah A.L. (2007) yeast of yam in vitro rumen gas production technique to evaluate some ruminant feedstuffs. Appl.Sci.Res.,3(1):34-41

Shahjalal, M., Selim, A.S.M. and Rahim, A. (1996) Effect of nitrogen fertilization on yield, chemical composition and in vitro organic matter digestibility of maize (Zea mays) and oat (Avena sativa) fodder. Bangladesh J. of Ani. Sci. 25 65-72.

Stevens, E.J., H.D. Gardner and K.M. Eskridge, (1996). Phenology of dent corn and popcorn. I. Influence planting date on crop emergence and early growth stages. Agro. J., 78: 880-884.

Sumner, D.C., W.E. Martin and H.S. Etchegaray, (1995). Dry Matter and protein yield and nitrate content of piper Sudan grass response to nitrogen fertilization. Agro. J., 87: 351-374.

Van Soest, P.J.; J.B., Robertson and B.A., Lewis; (1991): Methods of dietary fiber, neutral detergent fiber and non-starch polysaccharide in relation to animal nutrition. J. Dairy Sci.74, 35833597. 


\title{
تأثير استخدام مصادر من الأسمدة المختلفة على محصول سورجم العلف وتقدير القيمة الهضمية وقياسات الطاقة بواسطة الكرش الصناعى.
}

محمد حسين الثريينى1 ، مرفت سيد حسن2 ،عزة محمد محمد بلر2، فاطمه شهاب الدين احمد 3 ، فاطمه عبد السلام احمد². 1-قسم الاراضي - كلية الزراعه -جامعه القاهزة.

\author{
2- المعهز الاقليمى للاغذيه والاعلاف - مركز البحوث الزراعيه - الجيزة
}

-3 معهد بحوث المحاصيل الحقلية - قسم بحوث محاصيل العلف - مركز البحوث الزراعية - الجيزة - مصر.

تم دراسة تاثيراستخدام المعدلات المختلفة من التسميد العضوى والمعدنى على علف السورجم. تم اجراء تجربة بمزرعة البحوث عن الفترة من2013 حتى 2014 فى كلية الزراعة جامعه القاهرة. نم تتفيذ التجربة بنظام القطع العشوائية بثلاث مكررات واشتملت التجربة على

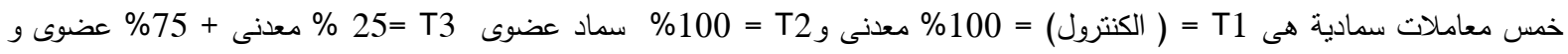

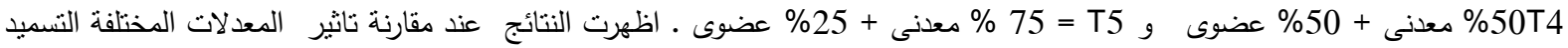
المعدنى والعضوى زيادة معنوية على كل من طول النبات ؛ سمك الساق ؛ الوزن الغض والوزن الجاف وذلك بالمعاملة T3 بالمقارنة بالمعاملات الاخرى وبالنسبة للتركيب الكميائى للنبات سجلت المعاملة T3 ارتفاع معنوى فى محنوى البروتين والنيتروجين خالى الازوت ولم يناثز الدهن

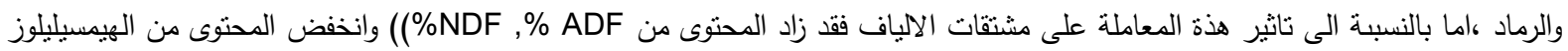
وارتفاع محتوى السليلوز بالمقارنة بالمعاملات الاخرى. وبدراسة ناثير المعدلات المختلفة من التسميد على خصائص التخمر الميكروبى بطريقة

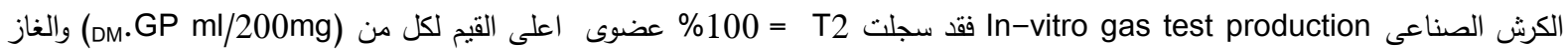

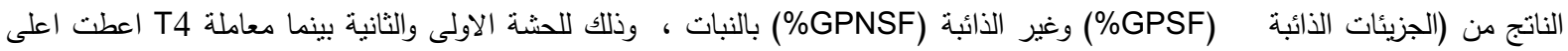

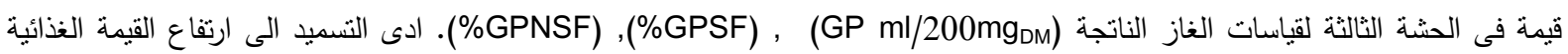

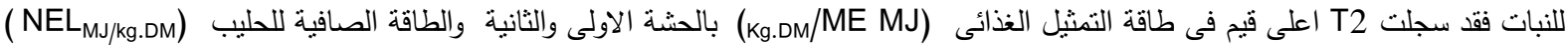
بالحشة الثانية وسجلت الاحماض الدهنية الطيارة قصيرة السلسلة mmol/mlgas CFA اعلى قيم بالحشة الاولى والثانية اما بالنسبة T4 الظهرت العلى العى قيم لهم فى الحشة الثالثة. سجلت T2 ارتفاعا معنويا فى نسبة المادة الجافة والعضوية المهضومة التى تحتوى على 100\% سماد عضوى فى الحى

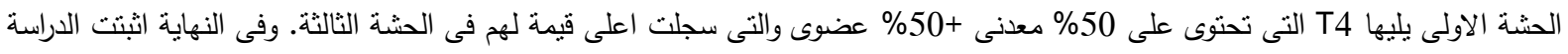

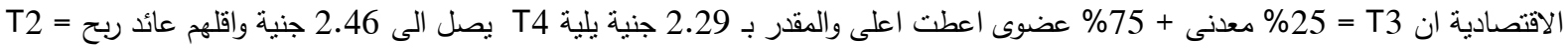
100\% عضوى التى اعطت عائد 1.90 جنية وهذا بالنسبة لكمية المحصول والحشات . بالنسبة للقياسات الهضمية بطريقة الكرش الصناعى الصى اثتت الدراسة ان T2 التى تحتوى على 100\% سماد عضوى اعطت اعلى قيمة هضمية للحشة الاولى والثانية يليها

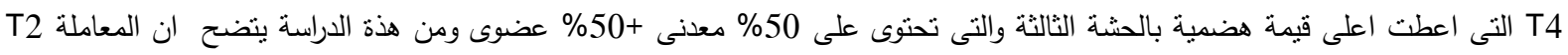

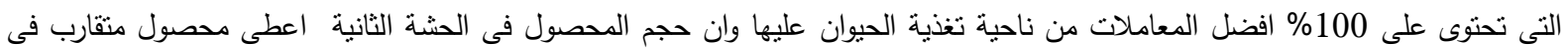

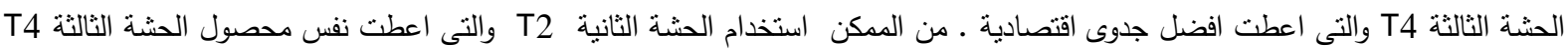
وفى هذة الحالة يكون وقت الزراعاقل ويعطى فرصة لااستخدام الارض فى زراعة محصول اخر بالاضافة الى انة يؤدى الى دخل اقتصادى .

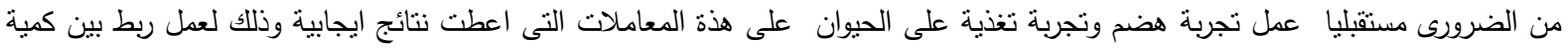
المحصول الناتجة فى الحشة الاولى والثانية ومعاملات هضمها وقياس كمية اللحم الناتج لتحديد الكفاءة الاقتصادية فى الحصول على على محصول كبير عالى الجودة وتقليل فترة الزراعة لتوفير الارض لزراعتها بمحصول اخر بالاضافة الى تقليل التلوث المعدنى للمياة الجوفية والتى مصدرة 